\title{
The Arthur Cox Foundation
}

Arthur Cox, solicitor, classical scholar and former president of the Incorporated Law Society of Ireland, was associated with the setting up of many Irish companies, not least the ESB. He was a specialist in company law and was a member of the Company Law Reform Committee which sat from 1951 and reported to the government in 1958, ultimately giving rise to the Companies Act 1963. When he decided to retire from practice as a solicitor in 1961 a number of his clients, professional colleagues and other friends, in recognition of his outstanding contribution to Ireland and his profession, thought that a fund should be established as a tribute to him, which fund would be used to encourage the writing and publication of legal textbooks. There was a generous response to this appeal.

After his retirement Arthur Cox studied for the priesthood and was ordained in 1963. He went to Zambia to do missionary work. He died there in 1965 as a result of a car accident.

The Foundation was established to honour Arthur Cox and was for many years administered by Mr Justice John Kenny in conjunction with the Law Society. John Kenny was the encouraging force behind the publication of a number of Irish legal textbooks. Without his quiet drive and enthusiasm there would have been no Foundation. To both Arthur Cox and John Kenny we pay tribute.

The Foundation's funds have been used to assist the writing and publication of Irish legal textbooks and the development of electronic databases of Irish legal materials. The Foundation has recently inaugurated an annual prize for the best overall results in the business and corporate law modules of the Law Society's Professional Practice Courses.

The Law Society, as the continuing trustee of the Foundation, is pleased to have been able to assist in the publication of this book.

Simon J. Murphy

President

Law Society of Ireland 
Laura Cahillane - 9781526114372 Downloaded from manchesterhive.com at 04/26/2023 01: 09: ๑9PM via free access 